\title{
Green Supply Chain Management Consideration Using Analitycal Network Process (ANP) Method in Supplier Selection in PT. XYZ
}

\author{
Satria Fitrah Wicaksana ${ }^{1}$ and Bambang Syairudin ${ }^{1}$
}

\begin{abstract}
The concept of Green Supply Chain Management (GSCM) is to integrate supply chain management with consumers, which includes the process of resource extraction, product design and development, distribution, waste disposal and recycle processes based on the thought of saving the environment. The problem found in this study is that suppliers pay little attention to environmental aspects as well as safety, delivery delays and quality. Government regulations related to the industry regarding the environment and the increasing number of people who switch to green products compel industry players to start incorporating environmental aspects into each of their production processes. This study uses the green supply chain management (GSCM) concept that integrates environmental aspects into business processes in the industry and discusses standardization of supplier selection. Selection of suppliers is an important problem that must be consider by the company in order to get suppliers who can support and improve the competitiveness of the company. The sample in this study was top management who worked at PT XYZ. Data collection techniques is using a questionnaire. The analysis of the green supplier selection was carry out using the Analytical Network Process (ANP) method because ANP is one method that is able to represent the importance of various parties by considering the interrelationships between the criteria and the existing subcriteria. Criteria for selecting suppliers are financial, environmental, quality, technical (service). An ANP linkage model is base on the identification of criteria and sub-criteria and the interrelationships between the two. All of the criteria and sub-criteria are compare with each other. The comparison scores are process and obtained scores for each alternative supplier. The results is obtained data quality criteria have a score of 0.319, environmental criteria have a score of 0.254 , technical criteria (service) has a score of 0.216 financial criteria has a score of 0.211. The supplier's recommendation is PT C because it has the highest score of 0.363 .
\end{abstract}

Keywords-Green Supply Chain Management, Supplier, Questionnaire, Analytic Network Proces.

\section{INTRODUCTION}

Supply Chain Management (SCM) is a strategic and systematic coordination based on traditional business functions and business tactics that serve to improve the long-term performance of the company and the overall

\footnotetext{
${ }^{1}$ Satria Fitrah Wicaksana and Bambang Syairudin are with Department of Business and Management, Institut Teknologi Sepuluh Nopember, 60111, Indonesia. E-mail: pofficialsafi@ymail.com; bambangsy@ie.its.ac.id.
}

supply chain [1]. With a focus aimed at customers, it requires a total supply chain strategy in the series that works together efficiently to create satisfaction at the end of the delivery point to consumers. Performance measurement in the supply chain is important to do as a parameter for evaluating the rate of return of inputs and can be use to attempt to improve supply chain conditions. Implementation of the concept of Supply Chain Management (SCM) is very important in influencing company performance. Supply Chain consists of all parties, both those directly involved and those involved indirectly in meeting customer demand [2]. Supply Chain Management is a series of processes for managing various activities with the aim of obtaining raw materials, followed by a transformation process to become a product, then a finished product and forwarded to shipping to consumers through a distribution system. This chain is also a network of parts that are interconnected and have the same goal, namely as best as possible to procure and distribute products [3]. The industry's challenges are increasing with the development of consumer awareness of environmental issues that require companies to implement environmentally friendly regulations. The production process is environmentally friendly, environmentally friendly raw materials. To get raw materials that are friendly to the environment, suppliers are need to implemented green production in the production process. Renewable innovations in environmentally friendly technologies that can save costs and save the environment are carry out with the aim of companies seeking profit. Percentage of consumers in recent years, Green Supply Chain Management (GSCM) is one of the important strategies to achieve sustainable development for the company. PT XYZ is part of Cotas Ltd for the Asia Pacific region. PT XYZ was first establish in Indonesia in 1940 in East Java. PT XYZ is one of the largest sewing thread manufacturers in the world.

PT. XYZ supplies all types of yarns from the household scale to the highest quality nylon bonded sewing thread for the shoe industry.

The use of nylon for the production of sewing thread, especially shoes, which dominates the use of raw thread materials in 2018, the use of nylon material in 2018 is $3,306,077$ tons. While the use of polyster for raw thread 
raw material in 2018 is only $3,264,241$ tons. This shows that the use of nylon for the production of sewing thread is far more than the use of polyester for the material. Therefore, in terms of selecting suppliers of nylon raw materials, it must be done properly and correctly so that the supplier must have criteria and sub-criteria that are in accordance with company requirements.

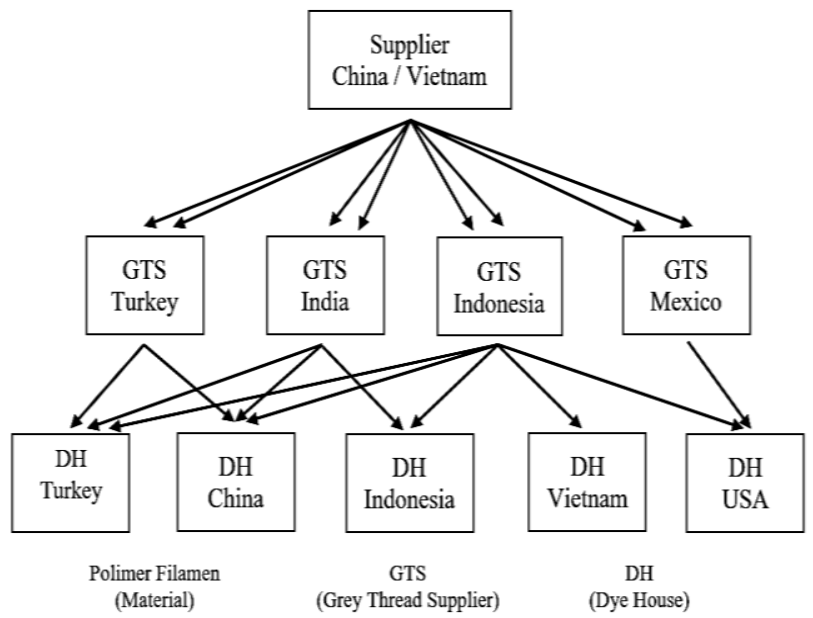

Figure 1. Grey thread supply chain PT XYZ.

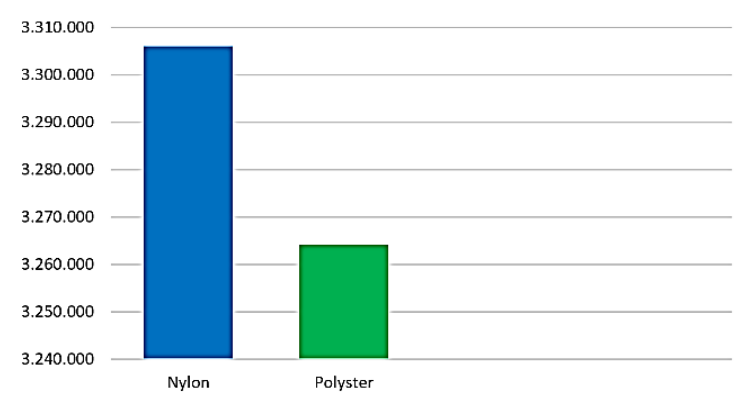

Figure 2. Graphics usage of nylon and polyster in 2018

\section{LITERATURE REVIEW}

\section{A. Legitimacy Theory}

The company must always ensure that it operates according to the norms in the community and the activities carried out can be accepted by parties from outside. This statement indicates that the company must ensure that its operations remain in line with the scores of the community. By maintaining harmony between company operations and community scores, the company will get the essence of operations that are in line with the expectations of the community. In the theory of legitimacy, it is said that companies will look for ways to maintain the sustainability of their business in a sustainable manner within the norms adopted by the community. The legitimacy theory can be concluded as a system that is in the interests of society. In its operations, the company must get support from the community. With this support, the performance of the company will increase due to the absence of external factors (society) that hinder the running of the company's operations. Legitimacy theory encourages companies to operate in a system that is appropriate in the community, so that the company is expected not to deviate and ensure that the company's operating activities can be accepted by the community.

\section{B. Selection of Supplier}

Supplier functions are very important for the development of manufacturing industries and service provider industries. Suppliers make a major contribution to the success of shipping goods originating from companies to then be sent to consumers. Supplier is a supply chain component that is in the leading position of the company. On the other hand, suppliers are people who are outside the company to ensure that the goods sent are in the appropriate standard conditions. The development of consumer segmentation and distribution opportunity flow exposes companies to determine distribution systems to more than one supplier. However, the more suppliers that are used by companies, the more difficult it will be to control and can create conflicts due to competing for customers and sales [4].

\section{Supplier Evaluation Criteria}

The best supplier is a supplier that is determined based on honesty, complete manufacturing facilities, and technology so that it can meet the needs of buyers, financial strength, price rationality, management policies, awareness of the need for continuous improvement and awareness that if suppliers serve customers well then their needs will also be fulfilled well. In general, there are three minimum criteria that are usually present in supplier assessment systems, namely quality, time, and cost. Quality criteria are generally interpreted as the suitability of the product with the specifications specified, the time criteria generally relate to the timeliness of delivery, while the cost criteria can include the costs the company must incur in doing business with its suppliers.

\section{Green Supply Chain}

In the last decade many companies have started competing to provide quality, cheap and fast products. If only relying on improvements in the internal sector, manufacturing companies alone will not be enough. To realize these aspects, the participation of many parties is needed, starting from suppliers as managers of raw materials to semi-finished materials, factories that process semi-finished materials into finished goods. All distribution networks that deliver products to arrive at the final consumer. Awareness of the importance of the role of all parties to create inexpensive, high-quality and fast products that initially gave birth to a new concept in the 1990s, namely the supply chain. The quality revolution that occurred at the end of the 1980s and the supply chain revolution in the early 1990s further clarified that best practices require the integration of environmental management with sustainable production operations [5]. 
This has prompted many companies to integrate green aspects in the supply chain concept. If a company wishes to achieve sustainability in environmental aspects, management must expand their business to improve practices related to the environment along the supply chain flow. Green supply chain has a very important role in the successful implementation of industrial ecosystem and industrial ecology. All activities along the supply chain have risks and negative impacts on the environment. Therefore, supply chain management is needed by considering the environmental impact of all production processes in order to protect the environment, including:

- Environmentally friendly manufacturing processes

- Reverse logistics

- ISO 14001 Environment management standard

- Waste management technology

The main function of measuring green supply chain performance is to create an effective and efficient supply chain that is environmentally friendly. One of the fundamental aspects in measuring green supply chain performance is continuous measurement of performance and improvement. Effective performance management requires a performance measurement system that is able to evaluate green supply chain performance in a holistic manner.

\section{E. Green Procurement}

TABEL 1.

CRITERIA - SUBCRITERIA GREEN PROCUREMENT [6]

\begin{tabular}{ll}
\hline \hline Criteria & Sub-criteria \\
\hline \multirow{4}{*}{ Finansial } & Bid price \\
& Price stabilization \\
& Discount (discount) \\
& Payment system \\
\hline \multirow{5}{*}{ Environment } & Green process \\
& Waste treatment technology \\
& Standard environment management (ISO 14001) \\
& Use of natural materials \\
& Compatibility of material with specifications \\
& Reverse logistics \\
& ISO 9001 Certification \\
& Product warranty \\
\hline \multirow{5}{*}{ Technical } & Past performance \\
& Timeliness of delivery \\
& Responsive \\
& Amount of shipment \\
\hline \hline
\end{tabular}

Defined as a purchase that takes into account environmental aspects, consisting of involvement in activities that include the reduction, reuse and recycling of materials in the purchasing process. Green procurement is a solution for businesses that care about the environment and conservative economy, as well as the concept of getting a choice of products and services that minimize adverse impacts on the environment. Green procurement is presented in supplier selection, including:

- Materials that meet the environmental quality standards of green partners and pass the audit process in following regulations for substances related to the environment

- Consider choosing suppliers that have ISO14000, OHSAS18000 and or RoHS.

- Choose suppliers that control the use of hazardous substances in the list of company standards and obtain green certificate achievements

\section{F. Decision-making}

The core of the decision-making process is located in the formulation of various alternatives in accordance with those in the attention and in choosing the right alternative after evaluation (assessment) regarding its effectiveness in achieving the objectives desired by decision makers. One of the most important components of the decision making process is information gathering activities from which an appreciation of the decision situation can be made. If sufficient information can be collected in order to obtain a complete specification of all alternatives and the level of effectiveness in the situation that is being noticed in the manufacturing process or relative decision making is very easy. However, in practice it is very unlikely to collect limited funds, time and energy [7]. Ralp C. Davis in [8], argues that decisions are the end result of a thought process about a problem faced by dropping choices on existing alternatives. A decision is a definite answer to a question. Decisions must answer the questions discussed and relate to planning. Decisions can be in the form of actions against implementation that might deviate from the original plan. James A.F. Stoner in [8], Decision is a choice between several alternatives. Contains three meanings, namely:

- There are choices based on logic

- There is one of the best of several alternatives

- There are goals and objectives achieved, where the decision is closer to that goal.

\section{G. Analytic Network Process (ANP)}

Analytic Network Process or ANP is a general theory of relative measurement used to reduce composite priority ratios of individual ratio scales that reflect relative measurements of the influence of interacting elements regarding control criteria. The Analytic Network Process method is the development of the Analytical Hierarchy Process (AHP) method. The ANP method is able to correct the weaknesses in AHP in the form of the ability to accommodate the interrelationships between criteria or alternatives. Linkages to the ANP method are of 2 types, namely the interrelationships in a set of elements (inner dependence) and the interrelationships between different elements (outer dependence). The existence of this link 
causes the ANP method to be more complex than the AHP method. ANP is a new approach in the decision-making process that provides a general framework for treating decisions without making assumptions about the independence of elements at a higher level than elements at lower levels and about the independence of the elements in a level. The main concept in ANP is influence 'influence', while the main concept in AHP is 'preference' preference. In the ANP methodology, the data used is primary data obtained from interviews (in-depth interviews) with experts, practitioners, and regulators, who have an understanding of the issues discussed. Followed by filling out the questionnaire at the second meeting with the respondents. Data ready for ANP is the respondent's assessment of the problem which is the object of research on a numerical scale. The question in the ANP questionnaire was in the form of pairwise comparison (comparison of pairs) between elements in the cluster to find out which of the two had greater influence (more dominant) and how much the difference was seen from one side.

\section{RESEARCH METHODS}

The research methodology is a systematic procedure to find out the performance of a project more quickly and accurately which is used as a guide in conducting a study. The stages and steps of this research are presented in the form of a flowchart in Figure 3.

\section{ANALYSIS AND DISCUSSION OF RESEARCH RESUlTS}

\section{A. Network Model Designing}

Data processing in this study was carried out using the Analytic Network Process (ANP) method. The difference from ANP and AHP lies in the selection model where AHP acquisition models are hierarchically structured while the ANP selection model is not structured but is structured based on interdependence relationships between groups and elements. In addition to data processing, AHP is only able to arrive at the calculation of pairwise comparison matrices while the ANP method from the comparison matrix is forwarded to the supermatriks.

\section{B. Data Collection Phase 1}

Criteria for selecting suppliers in this study were obtained from the results of identification of criteria from journals and research and other references. Then adjusted to the conditions at PT XYZ.

\section{Compilation of Network Structures}

In making decisions, it is necessary to distinguish between hierarchical structures and networks that are used to reflect the parts. Hierarchy only illustrates a one-way functional dependency relationship, namely the dependence of the lower level on the upper component. The network is able to accommodate two-way functional dependencies, namely the lower and upper components are functionally.

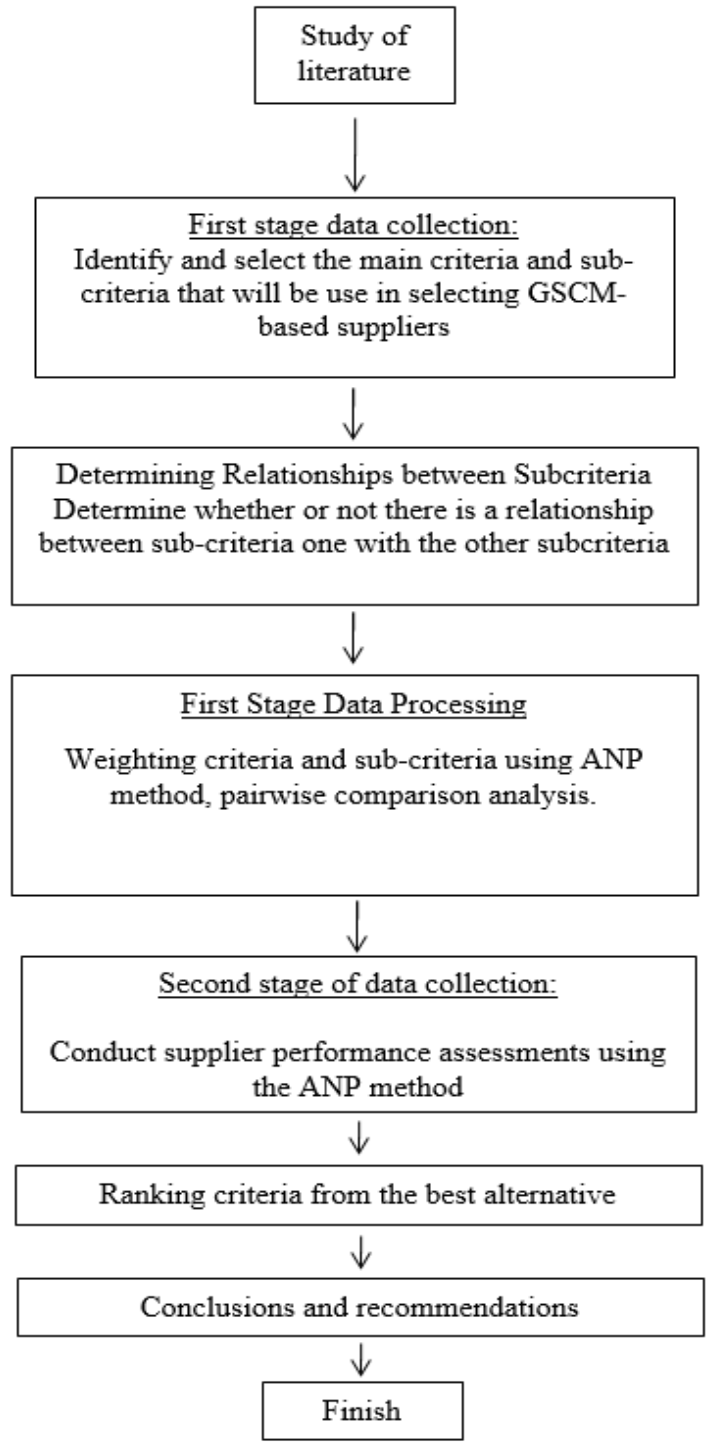

Figure 3. Research flow chart

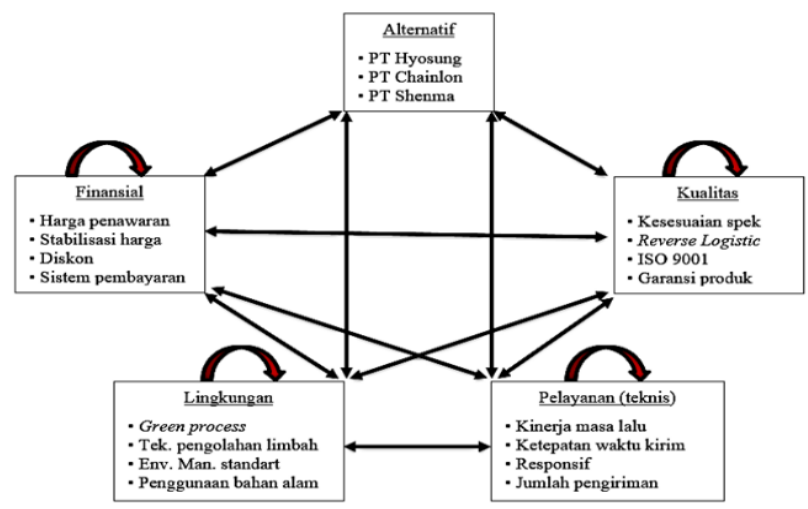

Figure 4. Network Structure Linkages Between Groups, Elements, and Alternatives in Supplier Selection 
The $1^{\text {st }}$ International Conference on Business and Management of Technology (IConBMT)

TABLE 2.

RELATIONSHIP BETWEEN GREEN PROCUREMENT SUB-CRITERIA

\begin{tabular}{|c|c|c|c|c|}
\hline Kriteria & Subkriteria & Inner Cluster & Inter Cluster & Sumber \\
\hline \multirow{5}{*}{ Finansial } & \multirow{2}{*}{ Bid price } & \multirow{2}{*}{ Discount } & Amount of shipment & \multirow{5}{*}{ [6], [9] } \\
\hline & & & Use of natural materials & \\
\hline & Price stabilization & & & \\
\hline & Discount & Bid price & & \\
\hline & Payment system & & Compatibility of material with specifications & \\
\hline \multirow{9}{*}{ Environment } & \multirow{2}{*}{ Green process } & & Compatibility of material with specifications & \multirow{9}{*}{ [6], [9] } \\
\hline & & & ISO 9001 Certification & \\
\hline & Waste treatment technology & $\begin{array}{l}\text { Environment management standart } \\
\text { (ISO 14001) }\end{array}$ & & \\
\hline & Standard environment management & Green process & & \\
\hline & $($ ISO 14001) & Waste treatment technology & & \\
\hline & \multirow{4}{*}{ Use of natural materials } & & Compatibility of material with specifications & \\
\hline & & & Bid price & \\
\hline & & & ISO 9001 Certification & \\
\hline & & & Amount of shipment & \\
\hline \multirow{4}{*}{ Quality } & $\begin{array}{c}\text { Compatibility of material with } \\
\text { specifications }\end{array}$ & Reverse logistics & Bid price & \multirow{4}{*}[6]{,$[9]$} \\
\hline & Reverse logistics & $\begin{array}{c}\text { Compatibility of material with } \\
\text { specifications }\end{array}$ & & \\
\hline & Sertifikasi ISO 9001 & Product warranty & Green process & \\
\hline & Product warranty & $\begin{array}{l}\text { Compatibility of material with } \\
\text { specifications }\end{array}$ & Timeliness of delivery & \\
\hline \multirow{4}{*}{ Technical } & Past performance & & Bid price & \multirow{4}{*}{ [6], [9] } \\
\hline & Timeliness of delivery & Past performance & & \\
\hline & Responsif & Amount of shipment & & \\
\hline & Amount of shipment & Responsif & Use of natural materials & \\
\hline
\end{tabular}

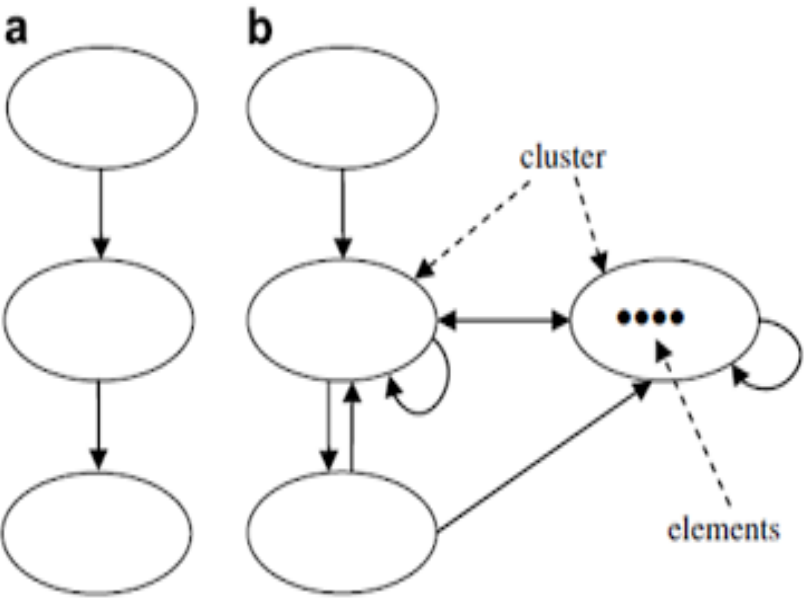

Figure 5. Differences in hierarchical (a) and network structures (b)[7]

\section{ANP modeling}

The ANP method is carry out with the help of the Superdecision program, where the process begins with the creation of a cluster model that shows the hierarchy between criteria, subcriteria, and alternatives. Through this model also will be seen the relationship between criteria, between subcriteria, and between subcriteria with alternatives.

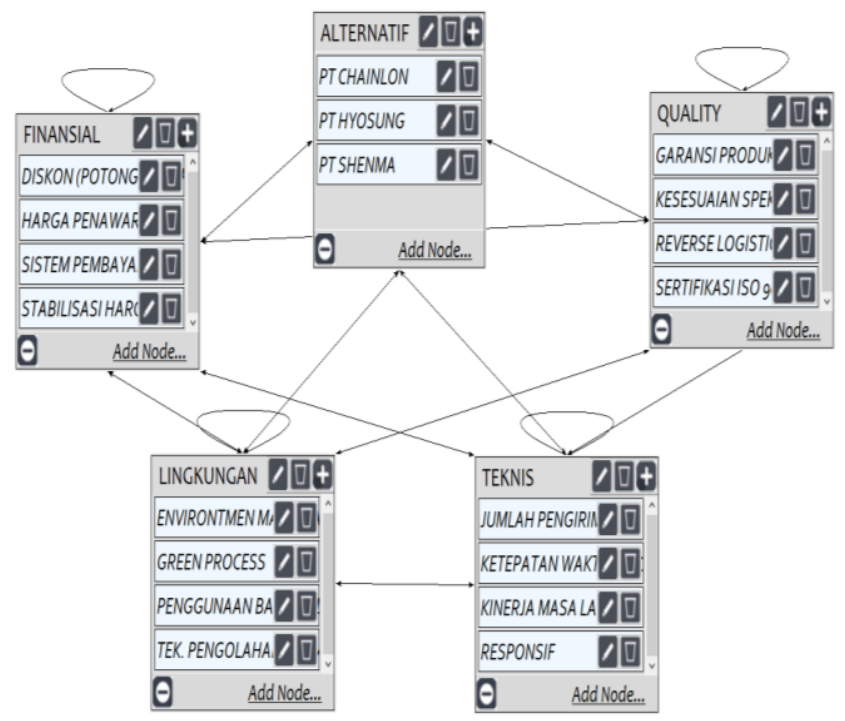

Figure 6. Model work on ANP with superdecision software 
The $1^{\text {st }}$ International Conference on Business and Management of Technology (IConBMT)

August 3rd 2019, Institut Teknologi Sepuluh Nopember, Surabaya, Indonesia

\section{E. Pairwise comparison ANP}

Comparison of criteria, subcriteria, and alternatives is done by using expert judgment. The experts chosen consisted of PT XYZ experts from the Material Planning department and Procurement department totaling three respondents. The department was chosen because it has the authority to determine suppliers who collaborate with PT XYZ. The relative scores obtained from the expert will be processed using the geometry average method. Following is the scale comparison of criteria scores in Table 3.

\section{F. Calculation of Each Subcriteria Weight}

The next step is to calculate the weight of interest for each sub-criteria based on the calculation results. There are four most influential criteria which are quality, environment, technical (service) and financial. At PT XYZ, Quality is a factor - a factor that can improve the quality of products that come from suppliers. The quality criterion has the greatest weight among all existing criteria which is equal to 0.319 followed by environmental criteria with a weight of 0.254 . Environmental management is the factors that indicate the efforts of suppliers to carry out environmental management. The third criterion is the technical criteria (service) with a weight of 0.216 and the least weight is the criteria for financial criteria with a weight of 0.211 . This shows that even though PT XYZ has begun to apply the eco industries concept, the selection criteria of PT XYZ suppliers still prioritize product quality. Environmental criteria as environmentally friendly aspects are second only to quality. This means that the supplier's environmental aspects are also considered by PT XYZ in determining supplier selection.

\section{G. Best Supplier Recommendations}

From the results of normalization of the limit score in the alternative group, we can find out the alternative rating. Data processing is done by ANP method by using Ms Excel and using super decision software.

TABEL 3.

SCALE OF SCORE COMPARISON [10]

\begin{tabular}{ccl}
\hline \hline Tingkat Kepentingan & Definisi & Keterangan \\
\hline 1 & Equal & Both elements have the same effect \\
3 & A little more important & Experience and judgment are slightly more partial to one element compared to their partners \\
5 & More important & Experience and judgment are very favorable to one element compared to their partners \\
7 & Very important & One element is well liked and practically its dominance is very real compared to its partner element. \\
9 & Absolute & One element proved to be absolutely preferred compared to its partner at the highest level of confidence \\
$2,4,6,8$ & Middle & Given if there is doubtful judgment between two adjacent judgments \\
Reverse & $a_{j i}=1 / a_{i j}$ & \\
\hline \hline
\end{tabular}

TABEL 4.

RECAPITULATION OF CRITERIA AND SUB-CRITERIA WEIGHT

\begin{tabular}{|c|c|c|c|}
\hline Kriteria & Bobot Kriteria & Sub-kriteria & Bobot Sub-kriteria \\
\hline \multirow{4}{*}{ Finansial } & \multirow{4}{*}{0,211} & Bid price & 0,065 \\
\hline & & Price stabilization & 0,054 \\
\hline & & Discount & 0,040 \\
\hline & & Payment system & 0,053 \\
\hline \multirow{4}{*}{ Environment } & \multirow{4}{*}{0,254} & Green process & 0,076 \\
\hline & & Waste treatment technology & 0,055 \\
\hline & & Standard environment management (ISO 14001) & 0,064 \\
\hline & & Use of natural materials & 0,059 \\
\hline \multirow{4}{*}{ Quality } & \multirow{4}{*}{0,319} & Compatibility of material with specifications & 0,113 \\
\hline & & Reverse logistics & 0,056 \\
\hline & & ISO 9001 Certification & 0,081 \\
\hline & & Product warranty & 0,068 \\
\hline \multirow{4}{*}{ Technical } & \multirow{4}{*}{0,216} & Past performance & 0,053 \\
\hline & & Timeliness of delivery & 0,061 \\
\hline & & Responsive & 0,059 \\
\hline & & Amount of shipment & 0,043 \\
\hline
\end{tabular}


TABLE 5.

DETERMINATION OF ALTERNATIVE SUPPLIER RATINGS

\begin{tabular}{|c|c|c|c|}
\hline Alternatif & $\begin{array}{c}\text { Nilai } \\
\text { Normalisasi }\end{array}$ & $\begin{array}{l}\text { Nilai dari limit } \\
\text { supermatrix }\end{array}$ & Peringkat \\
\hline PT H & \multirow[t]{2}{*}{0,292} & 0,041 & 3 \\
\hline PT S & & 0,049 & 2 \\
\hline PT C & 0,363 & 0,051 & 1 \\
\hline $\begin{array}{r}\text { CAPITULATION OF } \\
\text { MATRIX } \\
\end{array}$ & $\begin{array}{l}\text { TABEL } 6 . \\
\text { ENVECTOR SC } \\
\text { AINST EACH C }\end{array}$ & $\begin{array}{l}\text { ORE SUPPLIER I } \\
\text { F THE CRITERI } \\
\end{array}$ & $\begin{array}{l}\text { PERFORM } \\
\text { A }\end{array}$ \\
\hline Kriteria & PT H & PT S & PT C \\
\hline Finansial & 0,911 & 1,492 & 1,544 \\
\hline Environment & 1,309 & 1,113 & 1,544 \\
\hline Quality & 1,138 & 1,474 & 1,229 \\
\hline Technical & 1,175 & 1,200 & 1,520 \\
\hline Total & 4,53 & 5,28 & 5,84 \\
\hline
\end{tabular}

Based on the performance score of the four supplier selection criteria, it is obtained that the supplier's recommendation is PT $\mathrm{C}$ with a total score of 5.84, PT S with a score of 5.28, PT H of 4.53.

\section{CONCLUSION}

\section{A. Conclusion}

Based on the results of research on the application of Green Supply Chain Management with the Analytical Network Process (ANP) method in selecting suppliers of nylon raw materials at PT XYZ. then the conclusions obtained from the design model of a network are;

1. Based on the results of the phase one questionnaire. Obtained a design model of the relationship between elements in a network selection of suppliers of nylon raw materials for threads between elements, namely interrelated each criterion and sub-criteria that exist between one element with another. Financial sub-criteria are directly related to environmental, technical (service), quality and alternative criteria. Environmental subcriteria are directly related to financial, technical (service), quality and alternative criteria. Technical subcriteria (services) are directly related to financial, environmental, quality and alternative. Quality subcriteria are directly related to financial, environmental, technical (service), alternative criteria. Alternative subcriteria are directly related to financial, environmental, technical (service), and quality.

2. Using the ANP calculation, a nylon supplier for yarn is produced based on its priority score. The results obtained are quality criteria data has a weight of 0.319 , environmental criteria have a weight of 0.254 , the technical criteria (service) weighs 0.216 financial criteria weighing 0.211 . PT $\mathrm{C}$ has the highest priority score that is equal to 0.363 , the second priority is PT S with a score of 0.346 and the last priority is PT $\mathrm{H}$ with a score of 0.292 . After knowing the priority scores of each supplier's criteria, it can be concluded that the company can prioritize the procurement of nylon raw materials to PT C. This is because PT C excels in all criteria and sub-criteria in selecting nylon suppliers for sewing thread raw materials at PT XYZ.

3. The analysis comparison of the results of ANP method with the method used by the company.

TABEL 7.

COMPARISON OF ANP METHODS WITH THE METHODS USED BY THE COMPANY

\begin{tabular}{ll}
\hline \hline \multicolumn{1}{c}{ Criteria GSCM } & \multicolumn{1}{c}{ Criteria Konvensional } \\
\hline Quality & Quality \\
- Compatibility of material with & - Compatibility of material with \\
specifications & specifications \\
- Reverse logistics & - Reliability \\
- ISO 9001 Certification & - Percived Quality \\
- Product warranty & \\
\hline
\end{tabular}

Environment

- Green process

- Waste treatment technology Quantity

- Environment managemen standart ISO 14001

- Use of natural materials

\begin{tabular}{ll} 
Technical (service) & Continuity \\
- Past performance & - Serviceability \\
- Timeliness of delivery & \\
- Responsif & \\
- Amount of shipment & \\
\hline Finansial & Harga \\
- Bid price & - In-Voice \\
- Price stabilization & - Stabilisasi \\
- Discount & - Discount \\
- Payment system & - Payment system \\
\hline Alternatif & Alternatif \\
- PT C & $-P T H$ \\
- PT S & $-P T C$ \\
- PT H & $-P T S$ \\
\hline \hline
\end{tabular}

\section{B. Suggestion}

Some suggestions given to the company and the next researcher are as follows:

1. PT XYZ can apply the Analytic Network Process (ANP) method in selecting nylon suppliers, because with this method PT. XYZ gets a pretty clear picture of the weight of each criterion chosen as a consideration factor in choosing suppliers at PT XYZ based on green supply chain management compared to conventional methods that have been done previously by the company.

2. The need for additional testing is done, the decision in the selection of suppliers is done by other methods that suit the conditions. The method of total cost of ownership through activity based costing and integer programming if the purchasing activities of the material 
The $1^{\text {st }}$ International Conference on Business and Management of Technology (IConBMT)

August 3rd 2019, Institut Teknologi Sepuluh Nopember, Surabaya, Indonesia

carried out by the company at each supplier has a significant difference. The concept of taguchi loss function becomes necessary to be integrated when the company wants to know the potential value of financial losses due to differences or deviations that occur between the target value and the performance value of the sub-criteria. As well as further research, for the selection of suppliers on the material that really has a high risk to the environment so that the criteria for green supply chain management is a top priority.

3. PT. XYZ can apply the ANP method in selecting suppliers of materials other than nylon.

\section{REFERENCES}

[1] J. T. Mentzer et al., "Defining supply chain management," $J$. Bus. Logist., vol. 22, no. 2, pp. 1-25, Sep. 2001

[2] S. Chopra, Supply Chain Management: Strategy, Planning and Operation, 2nd ed. Upper Saddle River New Jersey: Pearson Education, 2004.
[3] R. E. Indrajit and R. Djokopranoto, Konsep Manajemen Supply Chain. Jakarta: PT. Gramedia Widiasarana Ind, 2002.

[4] A. Paskariska, "Analisis Pengukuran Kinerja Untuk Memilih Supplier Wheel Dengan Metode Analytical Hierarchy Process Di PT Suzuki Indomobil Motor," Universitas Pancasila, 2014.

[5] S. K. Srivastava, "Green supply chain management: A state of the art literature review," Int. J. Manag. Rev., vol. 9, no. 1, pp. 53-80, 2007.

[6] J. Sarkis, Greening the Supply Chain. London: Springer-Verlag London, 2006.

[7] J. Suprapto, Riset Operasi (Untuk Mengambil Keputusan). Jakarta. Jakarta: Raja Grafindo Persada, 2006.

[8] A. E. Saputro, "Sistem Pendukung Keputusan Penerimaan Pegawai Koperasi Serba Usaha Pijartirta Manunggal," STMIK AKAKOM Yogyakarta, 2014.

[9] A. H. I. Lee, H.-Y. Kang, C.-F. Hsu, and H.-C. Hung, "A green supplier selection model for high-tech industry," Expert Syst. Appl., vol. 36, no. 4, pp. 7917-7927, May 2009.

[10] T. L. Saaty, Fundamental of Decision Making and Priority Theory with The Analytic. Pittsburgh: RWS Publication, 1994. 